\section{ワイドギャップ半導体の表面・界面 (科学，技術，工学の連携)}

松波弘 之

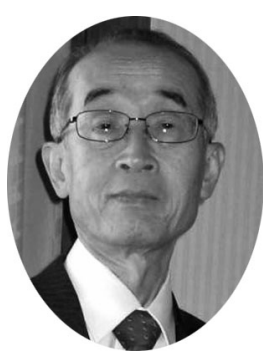

持続ある社会の発展のために，電気エネルギーの有効利用を目指すパワーエレクトロニクス が注目されている。電気エネルギーの発生から利用までの間に, 多くの半導体 $\mathrm{Si}$ パワーデバ イスが用いられているが，物性に起因する性能限界のため，飛躍的な発展は難しく，ワイドギ ヤップ半導体への期待が大きい。

中でも 4H-SiC（パワーデバイスに適した結晶多形で，以下， SiC と記す）は, Si に比べて, 高耐圧で，損失が 2 桁以上小さく，高周波動作に加えて，サイズが小型で, 高温動作による簡 易冷却ですむなどの利点がある。著者らが 1987 年に提示した (0001) オフ基板上での「ステッ プ制御エピタキシー」法で高品質成長層が得られる。現在は口径 4 インチの基板が市販され, ショットキーダイオード（SBD），JFET，MOSFET が商品化されている。

実用化されている SBD は，金属-半導体界面を活用するもので，著者らが 1995 年に提示し たものが基礎となっている。高性能のデバイスが可能となったので，基礎研究が必要との発想 から，仕事関数の異なる 3 種の金属をエピタキシャル成長層上に堆積し，ショットキー特性を 評価した。電流-電圧法，容量-電圧法，内部光電子放出法の結果から，障壁高さが金属の仕事 関数に比例（比例係数：0.70 0.76, 表面清浄化によりほほ 1.0）する結果が得られ，古典的な ショットキー障壁モデルが成立することを明らかにした。面方位で障壁高さが異なるなど，Si や GaAs で表面フェルミ準位がピン止めされ，金属の種類を変えても障壁高さがあまり変わら ないのと対比的である。障壁高さが選択できるので, 設計が可能となって, 商品化が続き, 上 市から 10 年以上経過して，信頼性が高く評価されている。科学，技術，設計を要する工学が 密に連携する好例である。

金属-酸化膜-SiC を活用する MOSFET も商品化され，実用 phase に入っている。 $\mathrm{SiC}$ 表面を 熱酸化し，それを窒化する方法が定着しつつあり，信頼性もよいが，物性から期待できる高性 能が出ていない。堆積酸化膜を使うなど，各種の方法で作製した MOSFET の性能と界面物性 の相関研究が盛んに行われているものの，決め手になる手法が明確ではなく，確定した結果と なっていない。基礎研究としては，結晶面方位を変えて熱酸化したときの界面物性が，面方位 によって異なることが明らかになっている。多くの MOSFET が(0001) Si 面， (000-1) 面に作ら れているが，(11-20)面，(1-100)，(0-38-3) 面で反転層の電子の移動度が大きい結果があり， 基礎研究に戻ることがたいへん重要である。表面・界面科学専門家への期待が大きい。

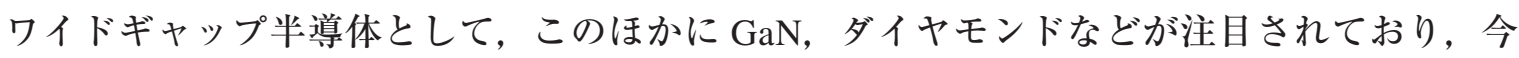
後 $\mathrm{SiC}$ がたどった表面・界面の基礎研究へ入っていくことが期待される。

(京都大学名誉教授)

Surface and Interface of Power Semiconductor SiC (Collaboration of Science, Technology and Engineering)

Hiroyuki Matsunami (Kyoto University, Professor Emeritus) 